\title{
Green Computing and Green Technology in e-Learning, Corporate, Business and IT Sectors
}

\author{
Shalabh Agarwal \\ Department of Computer \\ Science \\ St. Xavier's College \\ (Autonomous), Kolkata \\ India
}

\author{
Shreya Goswami \\ Department of Computer \\ Science \\ St. Xavier's College \\ (Autonomous), Kolkata \\ India
}

\author{
Asoke Nath \\ Department of Computer \\ Science \\ St. Xavier's College \\ (Autonomous), Kolkata \\ India
}

\begin{abstract}
E-learning is the use of technology to enable people to learn something anywhere and anytime. The delivery of a learning, training or education program by electronic means involves the use of a computer or electronic device such as a mobile phone in some way to make available training, educational or learning material. E-learning methods have drastically changed the educational environment and also reduced the use of papers and ultimately reduce the production of carbon footprint. E-learning methodology is an example of Green computing. Green Computing or Green IT refers to the study and practice of using computing resources in an eco-friendly manner in order to tone down the environmental impacts of computing. It is the practice of using computing resources in an energy efficient and environmentally friendly manner. To reduce unnecessary energy consumption due to hazardous materials has become a major topic of concern today. In the present paper the authors have discussed how Green Computing can be incorporated into different institutions, corporate/business sectors or may be in various IT companies.
\end{abstract}

\section{Keywords}

Green Computing, Green IT, Green Technology, Virtualization

\section{INTRODUCTION}

Due to economic budget constraint in all over the globe now the training budgets have been slashed. As a result of that the traditional training is now becoming almost impossible. This is because in the traditional training the trainers have to move from one place to another place and to do that they have to use flights or trains or any kind of automobiles which consumes money and the outcome is carbon footprint. Elearning can provide an environmentally friendly way to bridge this training gap, particularly in business sector where the staff are spread across different offices, regions or even countries. E-learning comes in many forms from fully featured interactive Web based courses that user can take in their own time to interactive virtual instructor led training (VILT) delivered using advanced training delivery interfaces such as Microsoft Live Meeting or the widely used Webex system. This saves lot of money and the environment also. Elearning adopts green computing methodology, where "Green Computing" is a term that implies a good, healthy and economically sensible environment. In Today's world Global
Warming, greenhouses gases, climatic changes and sustainable development are the key challenges. Thus for a

sustainable environment Green Computing should be enabled for the ecological balance in the environment. Green Computing is actually the study and practice of using and disposing of computers, servers and the associated subsystems such as monitors, printers, networking and systems of communications with minimal impact on nature.

The goals of Green Computing are:

(i) To reduce the use of hazardous materials.

(ii) To maximize energy efficiency during the lifetime o the products.

(iii) To recycle the defunct products and factory wastage in order to enable biodegradability.

Green IT is not any application which can be incorporated into any existing systems or a product. It is actually an improvement over the existing systems and the way to move forward with the existing IT infrastructure. It is now high time we start working towards keeping the air clean, save our valuable resources like soil, water, fuel sources for our successors apart from saving finances as this is the biggest asset which we can pass it down to the future generations. Green IT also refers to the solutions of IT that saves energy.

\section{Application of Green IT/Technology in some developing countries:}

Fifty-percent of business in the United States used Green Technologies as practices to improve energy efficiency within their establishments in August 2011, and over half used Green IT practices to reduce or eliminate the creation of waste materials as a result of operations. Green Technologies and Practices (GTP) survey data were collected from a sample of about 35,000 business establishments in the 50 states and the District of Columbia.

Use of technologies and practices to improve energy efficiency within the establishment, like occupying a LEED (Leadership in Energy and Environmental Design) certified building or using energy efficient lighting or programmable thermostats. 
Technologies or practices are also used to reduce greenhouse gas emissions through methods other than the renewable energy generation and energy efficiency including alternative transportation forms for the employees, such as carpools or mass transit.

Fig 1: Establishments using combinations of two Green Technologies and Practices as a percentage of all establishments using at least one Green Technology or Practice, August 2011: Source: U.S. Bureau of Labor Statistics

\begin{tabular}{|c|c|c|c|c|c|}
\hline $\begin{array}{l}\text { Green } \\
\text { Technology or } \\
\text { practice }\end{array}$ & $\begin{array}{l}\text { Generating } \\
\text { electricity, } \\
\text { heat or fuel } \\
\text { from } \\
\text { renewable } \\
\text { sources } \\
\text { within the } \\
\text { establishment }\end{array}$ & $\begin{array}{l}\text { Improving } \\
\text { energy } \\
\text { efficiency } \\
\text { within the } \\
\text { establishment }\end{array}$ & $\begin{array}{l}\text { Reducing gas } \\
\text { emissions } \\
\text { through } \\
\text { methods other } \\
\text { than renewable } \\
\text { energy } \\
\text { generation and } \\
\text { energy } \\
\text { efficiency } \\
\end{array}$ & $\begin{array}{l}\text { Reducing the } \\
\text { creation or release } \\
\text { of pollutants or } \\
\text { toxic compounds or } \\
\text { removing pollutants } \\
\text { or hazardous waste } \\
\text { from the } \\
\text { environment }\end{array}$ & $\begin{array}{l}\text { Reducing or } \\
\text { eliminating the } \\
\text { creation of } \\
\text { waste materials }\end{array}$ \\
\hline $\begin{array}{l}\text { Improving } \\
\text { energy } \\
\text { efficiency } \\
\text { within the } \\
\text { establishment } \\
\end{array}$ & 2.7 & N/A & 13.9 & 14.1 & 54.0 \\
\hline $\begin{array}{l}\text { Reducing gas } \\
\text { emissions } \\
\text { through } \\
\text { methods other } \\
\text { than } \\
\text { renewable } \\
\text { energy } \\
\text { generation } \\
\text { and energy } \\
\text { efficiency }\end{array}$ & 1.2 & 13.9 & N/A & 4.6 & 13.5 \\
\hline $\begin{array}{l}\begin{array}{l}\text { Reducing the } \\
\text { creation or } \\
\text { release of } \\
\text { pollutants or } \\
\text { toxic } \\
\text { compounds or } \\
\text { removing } \\
\text { pollutants or } \\
\text { hazardous } \\
\text { waste from the } \\
\text { environment }\end{array} \\
\end{array}$ & 1.3 & 14.1 & 4.6 & N/A & 14.6 \\
\hline $\begin{array}{l}\text { Reducing or } \\
\text { eliminating } \\
\text { the creation of } \\
\text { waste } \\
\text { materials } \\
\end{array}$ & 2.5 & 54.0 & 13.5 & 14.6 & N/A \\
\hline $\begin{array}{l}\text { Conserving } \\
\text { natural } \\
\text { resources } \\
\text { (excluding use } \\
\text { of recycled } \\
\text { inputs in } \\
\text { production } \\
\text { processes) }\end{array}$ & 1.5 & 21.0 & 6.7 & 8.9 & 22.1 \\
\hline
\end{tabular}




\section{METHODOLOGIES AND APPROACHES TOWARDS GREEN COMPUTING}

\subsection{Introduction of a subject "Green Technology" in the graduation level:}

Green Computing is a very important topic in the current scenario. Now it is necessary that in graduation or even in school level also there must be one subject called "Green Technology" to introduce the concept of Green IT and Green technology. This subject is now not only a theoretical subject on the other hand a full application oriented subject. The students should be trained from school/college level what we mean by Green Technology or Green IT. The student should be given some project on Green Computing or Green Technology. They should be allowed to do experiment on how to save energy.

A Computer is now a most important instrument for everyone in educational, commercial, corporate, banks, government sectors everywhere. Without this instrument no work can be done. So the use of computers must be optimum. The user should be given the knowledge of its proper utilization. Computers should not be used unnecessarily. Even if the user does not switch off the computer, they should power-down the CPU and all peripherals during the extended periods of inactivity. A user should also learn how to make use of the defective and outdated parts of the machine by recycling them instead of disposing them as wastage. In fact, after school level all sorts of study materials should be available as ematerial on net or in CDs. This will help in low use of printed materials. Hence, such knowledge must be incorporated into each individual so as to maintain eco-friendliness.

\subsection{Green Computing in IT Companies/Institution:}

In today's world, computing is not at all environment friendly. It is high time that things need to be changed. For a fresh new start, companies or businesses should be increasingly keen to make energy and cost savings in the face of rising electricity prices. Computing has a big area of human activities where real environmental savings need to be made implementing straight-forward practical measures with existing hardware. Software should be used such that it permits companies, institutions or individuals to measure and reduce the carbon emissions resulting from their computer use.
Power can be saved even when the computer is put into a "standby" or "sleep" mode as many people are not aware of the fact that shutting down a desktop computer does not completely turn it off. In Fig-1 we have shown how power is consumed by a lap-top and by a desktop computer. The fig shows that desktop is taking more power than a lap-top computer.

An IT company is totally incomplete without a PC; hence for different IT companies green PC's can be built. Many companies such as Intel have already developed Greener desktop computing in a big way with a high energy efficient processor called Atom. Hardware manufacturers should avoid using substances like lead, mercury, cadmium, beryllium, brominated flame retardants (BFRs) and polyvinyl chloride (PVC) to make computers. This can help more electronics waste to be safely recycled because these toxic substances never help in safe recycling.

\subsection{Green Computing in corporate/business sectors:}

Green technology along with green computing is referred to as the environmentally responsible use of computers and any other technology related resources. It includes implementing the best practices such as energy efficient CPU's, peripherals and servers. It offers cost reduction and operational benefits to the network managers. For an entire organization, technologies like Cloud Computing are a great alternative. It eliminates the need for hardware like servers. This is also termed as Virtualization, where Cloud computing replaces hardware with "virtual" servers or servers in "the cloud". It allows corporate or business sectors to reduce their need for bulky, big and energy-consuming servers by relocating them on the Internet. This Cloud Computing must be used in areas such as data storage, networking, software applications, operating systems, thus reducing the need for the hardware in a particular business sector. Henceforth, corporate or business sectors can save a lot of money, time and resources on maintenance and support.

In any business environment, paper-based work includes several forms, documents, notes, call activities, sales logs, quotes and contracts. It may also include mailing and faxing hardcopy quotations or sales orders and printing various reports of purchasing, etc. These can be replaced by working online thus saving a lot of paperwork. 
Fig 2: Desktop And Laptop Power Consumption (In Watts).

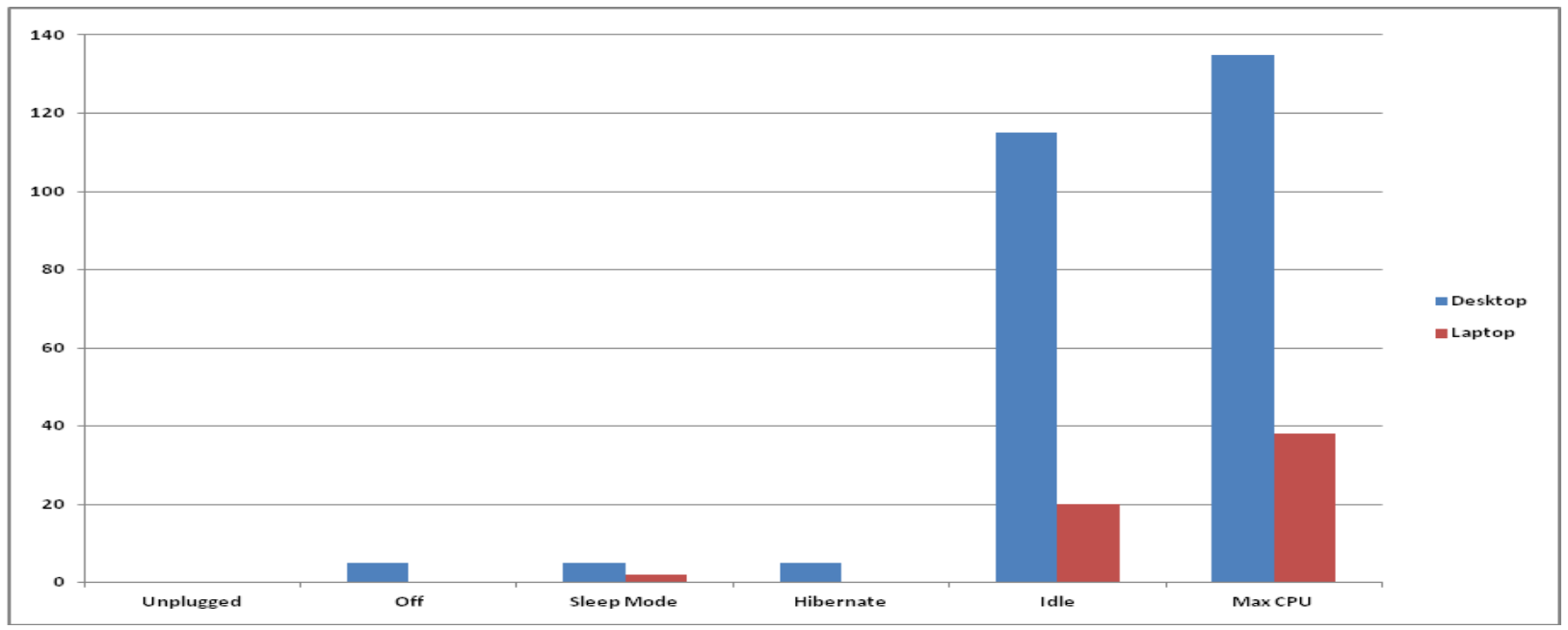

\subsection{To design Green Software and the corresponding green Operating System} $(\mathrm{O} / \mathrm{S})$ :

The aim of designing green software is Sustainable Software Development and the use of Open Source methodologies. Sustainable Development is termed as balancing the economic growth and social needs with the natural environment which should be achieved so that the growth in the present does not sacrifice the future opportunities adversely. These developments refers to specialized software engineers and developers who should design, build and maintain the networks of data collection systems, sensors and different probabilistic modeling so as to support smart energy grids, alternative energy production and other systems to substitute intelligence for natural resources. Open Source is a driven approach that is not linked to any vendor/supplier. It is widely supported by environmentally conscious proponents using fewer resources, thus being more efficient.

The future operating system should be network based and it would be efficient in running network applications via Cloud Computing. Power consumption should be handled at both the levels: end user and server level. Linux is considered to be green $\mathrm{OS}$ as it is more environmentally friendly relative to proprietary systems. It has efficient power consumption mechanism. Associated with the power savings are reduced carbon emissions.

\subsection{Power Control Management:}

Replacement of light bulbs at home, or any institutions, working sectors and even at the streets or stadiums must be done immediately with energy-efficient ones. This will enable huge savings of power. But it is to be ensured that they are not mercury-vapor light bulbs because when they go to the trash/recycling center, they are full of poisonous mercury. Tracking should be kept to progress towards the carbon emission goals.

The power can be controlled by using LCD monitors instead of CRT monitors. PC's alone consume anywhere from 50250 watts of energy! The monitor itself consumes tons of energy with a traditional CRT monitor. On the other hand, Laptops use far less energy at around 45 watts and are more energy efficient than the desktop computers. A laptop is always better to use than a desktop computer as it uses $1 / 3$ of the energy and is portable thus taking up less room. Even setting the "sleep" functionality on one's computer is a great idea when one forgets to turn it off! The best way to save money on computer energy use is to turn off and unplug the computer when not in use.

Additional energy can be saved on top of the savings of computer. Common accessories like printers, modems, routers, speakers, etc are used by most of the people. The printer is one of the larger energy users of all computer accessories. All-in-one printers use much more energy than traditional printers as they have much functionality. Many accessories like the router and modem are not able to go into "standby" mode and therefore run at all times. So, its better to turn them off or unplug them when not in use. The table helps us to compare the power consumption by various computer units: 
Fig 3: Consumption Of Power By Different Computer Unit

\begin{tabular}{|l|l|}
\hline COMPUTERS & POWER CONSUMED \\
\hline Desktop Computers & $60-250$ watts \\
\hline On screen saver & Same as above \\
\hline Sleep / Standby & $1-6$ watts \\
\hline Laptop & $15-45$ watts \\
\hline MONITOR & POWER CONSUMED \\
\hline Typical 17' CRT & $\sim 80$ watts \\
\hline 19' LCD & $17-31$ watts \\
\hline 20-24' LCD & $18-72$ watts \\
\hline Screensaver (Image on screen) & Same as above \\
\hline Sleeping Monitor (Dark Screen) & $0-15$ watts \\
\hline Monitor turned off at switch & $0-10$ watts \\
\hline
\end{tabular}

Fig 4: Consumption Of Power By Mac And Personal Computer

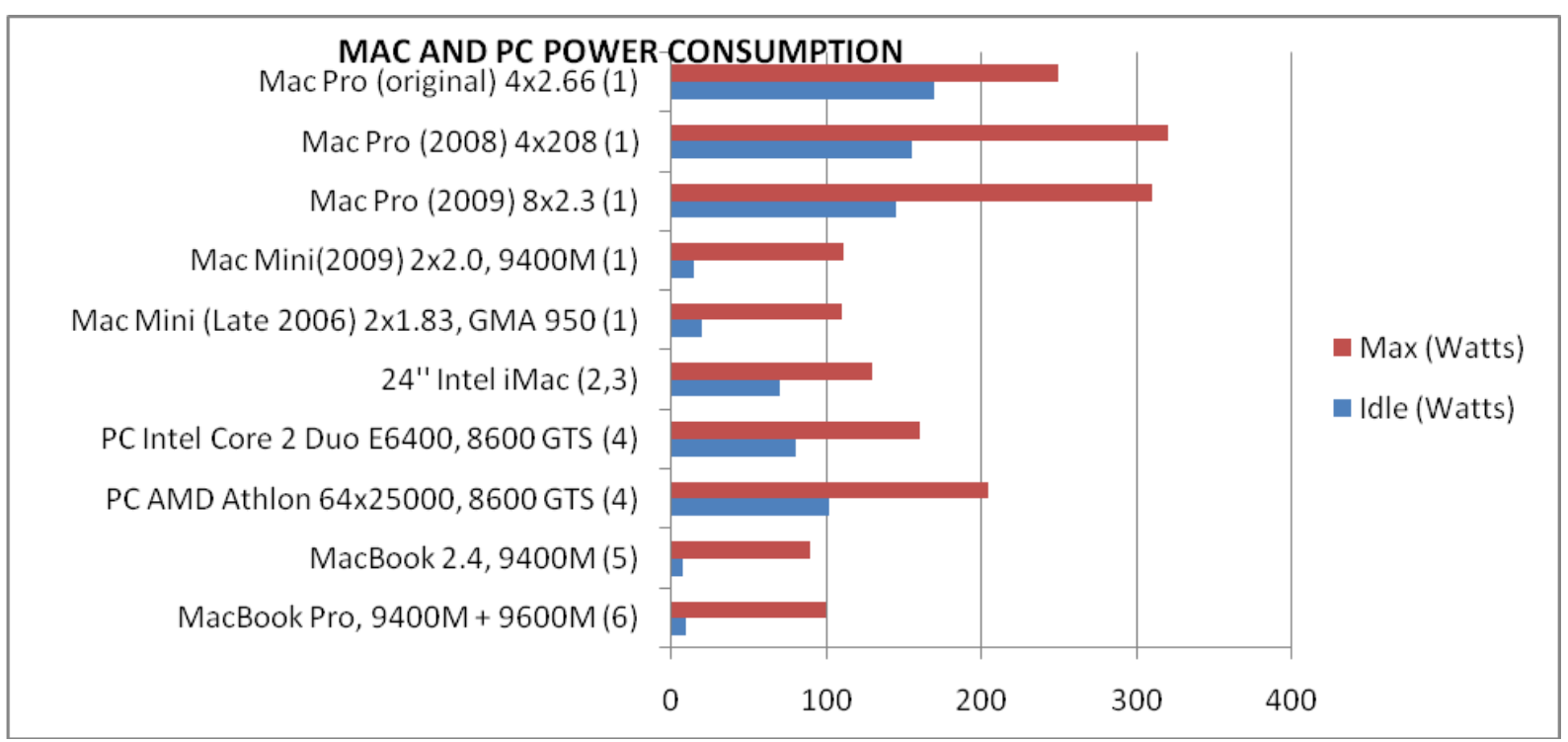

\subsection{Utilization of Energy in a green way:}

As we all know from the very beginning that Energy can neither be created nor be destroyed but conserving energy is the most important of all today. Energy efficient computers can be used as an alternative now. Apart from this online threats also contribute to the growing climate crisis. Viruses, spyware and malware draw on the processing power of our computer, even when we aren't using it. This consumes energy and adds to $\mathrm{CO}_{2}$ emissions. So it is better to use anti-malware services which can protect businesses and reduce the overall energy consumption and thus electric bills.

The institutions should also start to use solar energy so as to save a lot of valuable energy on Earth. In 2011, The
International Energy Agency said that "the development of affordable, inexhaustible and clean solar energy technologies will have huge longer-team benefits. It will enhance sustainability, reduce pollution, lower the costs of mitigating climate change, and keep fossil fuel prices lower than otherwise. These advantages are global."

Solar energy technologies are designed to use the sun's energy to heat homes, provide lighting, create hot water, or generate electricity. Computers also play an essential role in solar power systems especially to maximize energy efficiency. Solar cells also require very little maintenance throughout their lifetime. It does not require any cost other than the initial installation costs and thus provides energy at virtually no cost.

Fig 5: Hardware Energy Usage Profile (In Watts).

\begin{tabular}{|l|l|l|}
\hline COMPONENT & IDLE POWER USAGE & MAXIMUM POWER USAGE \\
\hline CPU & 40.8 & 130 \\
\hline HDD & 14.35 & 17 \\
\hline VIDEO & 18.3 & 25.6 \\
\hline NETWORK CARD & 4.95 & 4.95 \\
\hline CD / DVD & 2 & 18 \\
\hline
\end{tabular}


Fig 6: Usage Of Computers At Home

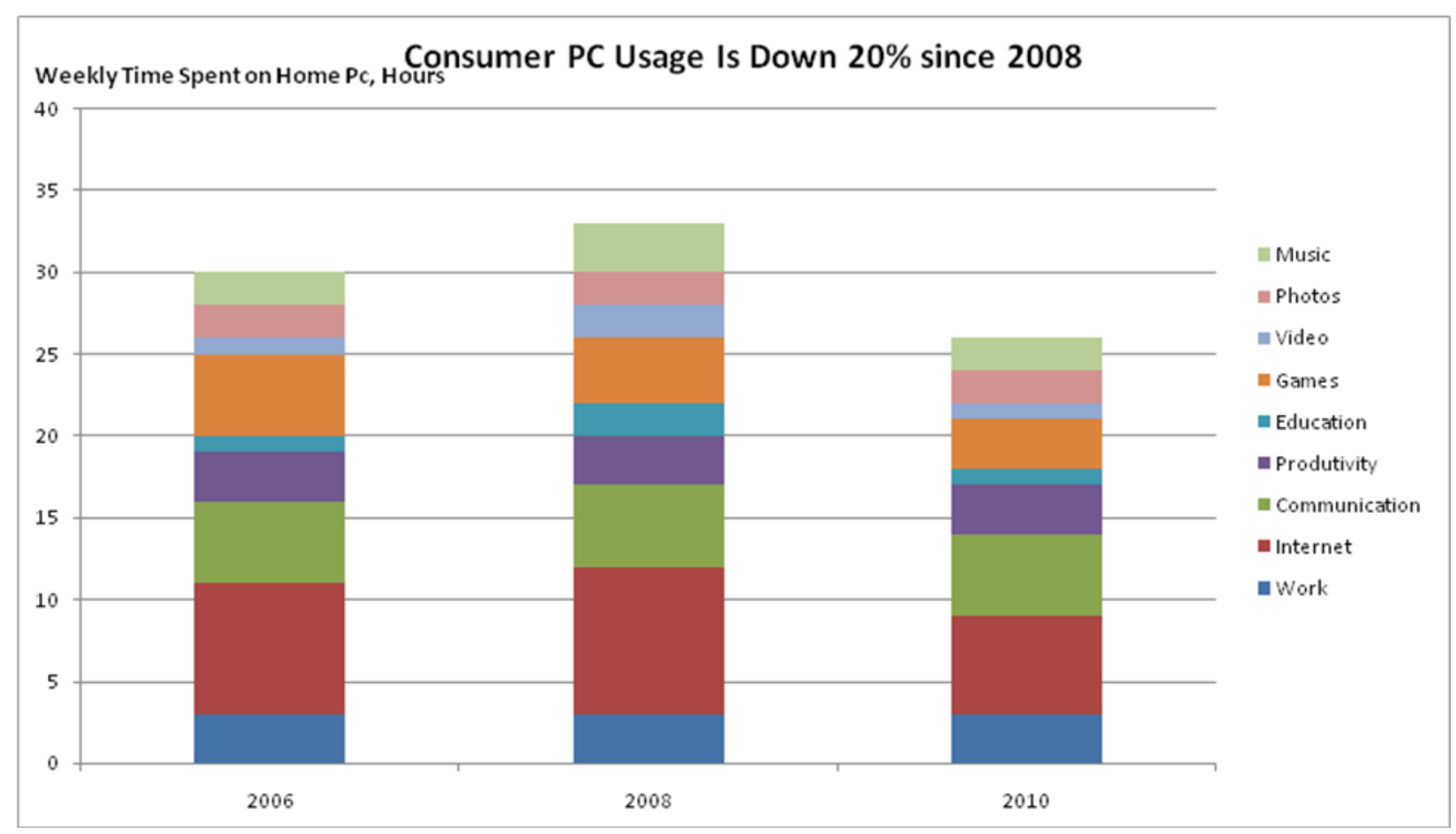

\subsection{Mobile Computing should replace all other computing:}

Mobile computing is "taking a computer and all necessary files and software out into the field." Mobile phones have emerged out to be a better option in comparison to Computers. Computers are generally needed for surfing the internet, chat, gaming, social networking, downloading, uploading, desktop computing including documents, spreadsheets, working on presentations, watching photos, videos and listening to music.

Today's mobile phones have all the above mentioned functions integrated in it. It has a large memory space in it, processors working in very high speed, more RAM, faster wireless Internet connectivity but they consume much low power compared to the Computers.

Students can study using the mobile phones where there are applications that enable them to go through the e-books, give online examinations and publish e-paper. Ematerials should be available so that anybody can download it and study. College and University examinations should be modified to online examinations. The Teachers also should check the answer papers online. The Teachers should make it a point to teach the students on-line so as to reduce the production of carbon foot print. Thus mobile computing helps in reduction of power, costs of communicating from one place to another place and being more energy efficient.

Thus Green Computing or Green Technology should be practiced in the best possible way to mitigate the climatic changes and increase the eco-friendliness on earth. The potential approaches to Green computing are power management, energy efficiency, working online, e-mail, virtualization, and cloud computing. For the success of the green initiatives taken in Higher Education Institutes, awareness and proper implementation of the concepts should be taking place. There is also a need to make individuals, students and management aware of the benefits of Green Computing in terms of sustainability and cost savings through different programmes. The primary objective of the IT policy makers in Higher Educational Institutes should be spreading the awareness about sustainable computing and implementation of green computing initiatives. However, green practices should be inculcated within the students so that they can put it in practice in their future endeavors.

\section{CONCLUSION}

Green Computing or Green Technology should be practiced in the best possible way to tone down the climatic changes and increase the eco-friendliness on earth. The potential approaches to Green computing are power management, energy efficiency, working online, e-mail, virtualization, and cloud computing. For the success of the green initiatives taken in Higher Education Institutes, awareness and proper implementation of the concepts should be taking place. There is also a need to make individuals, students and management aware of the benefits of Green Computing in terms of sustainability and cost savings through different programmes. The primary objective of the IT policy makers in Higher Educational Institutes should be spreading the awareness about sustainable computing and implementation of green computing initiatives. However, green practices should be inculcated within the students so that they can put it in practice in their future endeavors. '

\section{ACKNOWLEDGMENTS}

The authors are very much grateful to Department of Computer Science, St. Xavier's College (Autonomous), Kolkata for providing the means to carry out the research work. The discussions and suggestions from the fellow educators and colleagues are also acknowledged. Gratitude is also extended to UGC, India for their support through a Minor Research Project in the area of Green Computing \& IT. 


\section{REFERENCES}

[1] Dick, M, Naumann, S \& Kuhn, N 2010, 'A Model and Selected Instances of Green and Sustainable Software'. What Kind of Information Society? Governance Virtuality, Surveillance, Sustainability, Resilience. 9th IFIP TC 9 International Conference, HCC9 2010 and 1st IFIP TC 11 International Conference, CIP 2010, Held as Part of WCC 2010, Brisbane, Australia, September 2023, 2010. Proceedings, eds J Berleur, MD Hercheui \& LM Hilty, IFIP International Federation for Information Processing, Berlin, Heidelberg, pp. 248259. Available from http://dx.doi.org/10.1007/978-3642-15479-9_24.

[2] Dick, M \&Naumann, S 2010, 'Enhancing Software Engineering Processes towards sustainable Software Product Design' in EnviroInfo 2010. Integration of Environmental Information in Europe. Proceedings of the 24th International Conference on Informatics for Environmental Protection Cologne/Bonn, Germany, eds K Greve\&AB Cremers, Shaker, Aachen, pp. 706- 715.

[3] Fischer, J, Naumann, S \& Dick, M 2010, 'Enhancing Sustainability of the Software Life Cycle via a Generic Knowledge Base' in EnviroInfo 2010. Integration of
Environmental Information in Europe. Proceedings of the 24th International Conference on Informatics for Environmental Protection Cologne/Bonn, Germany, eds K Greve\&AB Cremers, Shaker, Aachen, pp. 716-725.

[4] White Paper: 5 Steps to a Successful Green Computing Solution, Mainline Information system.

[5] A Guide to the conscientious purchase, use and disposal of ICT, November 2010, Global E-Schools and Communities Initiative.

[6] Green IT: Why Mid-size Companies Are Investing Now, Info-Tech Research Group, Toronto. Ontario M5E 1B3

[7] W. Feng and K.W. Cameron. The Green500 List: Encouraging Sustainable Supercomputing. pages 50\{55. IEEE Computer Society, 2007.

[8] I. Foster, Y. Zhao, I. Raicu, and S. Lu. Cloud Computing and Grid Computing 360-Degree Compared. In Grid Computing Environ-ments Workshop, 2008. GCE'08, pages $1\{10,2008$.

[9] Tao Chen, yang yang, honggang zhang, haesik kim, kari horneman - - Network energy saving technologies for green wireless access networks\| IEEE Wireless Communications October 2011 